HID 47 (2020)

\title{
MÚSICOS ANTE LOS TRIBUNALES CIVILES Y RELIGIOSOS (SIGLOS XVII-XVIII) $^{1}$
}

\author{
MUSICIANS TO CIVIL AND RELIGIOUS COURT \\ (17TH-18TH CENTURIES)
}

\author{
Clara Bejarano Pellicer \\ Universidad de Sevilla \\ cbejarano@us.es ORCID: https://orcid.org/0000-0003-0389-5164
}

RESUMEN: La sociedad barroca vivió un clima de irritabilidad notable, explicado por las circunstancias, por muy diversas razones, que afectó a todos sus integrantes. Los músicos, conocidos por su temperamento conflictivo, también protagonizaron muchos incidentes, aunque en una proporción mínima desembocaron en los tribunales de justicia. Este trabajo se propone analizar una muestra de pleitos civiles y religiosos que afectaron a músicos del mundo hispánico en los siglos XVII y XVIII, con el objetivo de distinguir las causas que les movían y perjudicaban en mayor medida o aquellas faltas que la sociedad barroca consideraba imperdonables en los músicos. Esto revelará si efectivamente la mala fama de este grupo socioprofesional está basada en una realidad contrastable. Esto ofrece interés con vistas al estudio de la profesión musical en el Barroco hispánico y asimismo de la conflictividad social propia de entonces.

PAlabras ClaVE: músico; pleito; conflictividad; justicia; deuda; tribunal.

ABSTRACT: Baroque society had a noticeable atmosphere of irritability, explained by circumstances and different reasons, which affected all its members. Musicians, known for their troublesome nature, also starred a lot of incidents, though barely led in courts. This paper propose to analyze a sample of civil and religious lawsuits that affected musicians from Hispanic world in $17^{\text {th }}$ and $18^{\text {th }}$ centuries, with the objective of standing out the causes that drove and damaged them the most or the musicians' offences that Baroque society considered unforgivable.

Recibido: 10-4-2019; Aceptado: 4-10-2019; Versión definitiva: 27-3-2020

1. Abreviaturas utilizadas: $\mathrm{ACA}=$ Archivo de la Corona de Aragón; $\mathrm{AHN}=$ Archivo Histórico Nacional; $\mathrm{ARCHV}=$ Archivo de la Real Chancillería de Valladolid; exp=expediente; $\mathrm{p}=$ página; $\mathrm{pp}=$ páginas; vol=volumen.

Copyright: (C) Editorial Universidad de Sevilla. Este es un artículo de acceso abierto distribuido bajo los términos de la licencia de uso y distribución Creative Commons Reconocimiento-NoComercialSinObraDerivada 4.0 (CC BY-NC-ND 4.0) 
This will reveal if the bad reputation of this socioprofesional group in fact is based in a contrastable reality. This is interesting to the study of musical profession in Hispanic Baroque and social conflicts.

KEYWORDS: musician; lawsuit; divisiveness; authorities; debt; court.

Se ha definido a la sociedad barroca como una sociedad conflictiva ${ }^{2}$, incluso violenta, toda vez que se estudia la violencia en su contexto social, como un elemento cotidiano estructural y no como una excepción que es el crimen, y en su faceta física y también simbólica ${ }^{3}$. No obstante, no se la puede definir como una sociedad especialmente violenta, en comparación con otras épocas, sino tener en cuenta que la violencia estaba imbricada en el sistema por razones políticas (construcción del Estado en proceso), económicas (pobreza desarraigadora), de costumbres (poseer y portar armas era común), mentales (exacerbado sentido del honor $)^{4}$. La violencia estaba justificada en el ámbito judicial, familiar y de honor ${ }^{5}$. Por lo tanto, no era tan sólo fruto de pulsiones, sino actos culturales.

Dentro de estas dinámicas sociales, los músicos como grupo, a tenor de las fuentes del Antiguo Régimen, gozaban de la dudosa reputación de conflictivos. Por un lado, se registra una elevada incidencia de conflictividad laboral, puesto que en todas las capillas catedralicias españolas de la Edad Moderna podemos hallar casos de despidos fulminantes individuales o colectivos por razones de disciplina. Muchas de sus faltas estaban relacionadas con el absentismo laboral (sobre todo en el caso de los instrumentistas), y otras con enfrentamientos verbales o corporales entre ellos o con los canónigos en público (los cantores se revelaban especialmente soberbios), a veces multilaterales. Incluso se pueden destacar algunas huelgas musicales que tenían como objeto avergonzar a la institución empleadora en contextos diseñados para su exhibición social ${ }^{6}$. Por el otro lado, se conocen múltiples casos de músicos procesados y encarcelados, a veces por deudas y otras por delitos no siempre conocidos, entre los que se cuentan robos, difamaciones, peleas, seducciones, raptos, violaciones e incluso homicidios. Su implicación en actos violentos ha sido objeto de algunos estudios en el ámbito italiano ${ }^{7}$, sin que en nuestro país haya ejemplos trabajados de manera sistemática y no anecdótica ${ }^{8}$.

La inmensa mayoría de los datos anteriores se obtienen de fuentes propias de las instituciones que emplearon a los músicos, y que recogen pormenores sobre su organización interna. Sin embargo, las actitudes conflictivas de los músicos fuera de su ámbito de trabajo quedan en la sombra, salvo alguna referencia casual y descontextualizada. El objetivo de este trabajo consiste en analizar cuál fue la

2. Lozano Navarro, Castellano, 2010; López-Guadalupe, Iglesias Rodríguez, 2012.

3. Pascua Sánchez, 2012.

4. Iglesias Rodríguez, 2012a.

5. Iglesias Rodríguez, 2012b, p. 45.

6. Bejarano Pellicer, 2013, pp. 96-107.

7. Por ejemplo, Getz, 2005, p. 175. Rostirolla, 1994.

8. Tan sólo se puede citar Bejarano Pellicer, 2012. 
incidencia de la conflictividad social que implicó a músicos (cantores, instrumentistas, organistas, maestros de capilla), a través de la muestra visible del fenómeno que son los pleitos ante la justicia. Se realizará un catálogo de los roles y delitos en los que podemos encontrar a los músicos ante los tribunales, ofreciendo una selección de ejemplos procedentes de diversas instancias de justicia de Castilla y Aragón de los siglos XVII y XVIII, con el fin de conocer el hipotético perfil conflictivo que mostraba este grupo socioprofesional ante las autoridades y la sociedad. De esta forma se revelará si efectivamente los prejuicios sobre este grupo estaban basados en una realidad contrastable.

Los tribunales que utilizamos, por corresponder a altas instancias y por lo tanto conservar grandes fondos, serán el santo Oficio de diversas ciudades (Barcelona, Zaragoza, Valladolid, Santiago de Compostela, Cuenca, Murcia, Puebla de los Ángeles), la Universidad de Alcalá de Henares, la Real Audiencia de Barcelona, la Real Chancillería de Valladolid y el Consejo de Castilla.

Las fuentes judiciales son especialmente valoradas por su muestrario de costumbres y realidades cotidianas que escapan a otros retratos, revelando las categorías mentales, las redes sociales e incluso el léxico que alimentaba la conflictividad $^{9}$. No obstante, tienen sus limitaciones. Se registra un alto número de casos que fueron llevados a los tribunales pero no seguidos hasta el fin, pues el mero hecho de denunciar ya provocaba la resolución del conflicto fuera del procedimiento judicial, ya sea en la casa, la vecindad o la corporación (formas alternativas de control social). La sociedad también definía el papel del sistema judicial mediante su uso, y no olvidemos que en los siglos XVII y XVIII los altos costes que implicaba recurrir a la justicia hicieron que ésta se convirtiera en algo más exclusivo y profesional. Tan sólo ciertos delitos se llevaban a los tribunales, en especial en grado de reincidencia, pues tan sólo una parte de la sociedad utilizaba la justicia para imponer sus intereses sobre el conjunto ${ }^{10}$. Por lo tanto, la muestra que veremos no es exactamente representativa, aunque sí nos ofrece indicios. No obstante, en la sociedad castellana se registra una actividad litigante superior, señal de que la cultura jurisdiccional castellana inspiraba confianza a la sociedad a pesar de que el magistrado aplicaba ante todo la jurisprudencia de acuerdo con su interpretación ${ }^{11}$.

\section{TRIBUnALES RELigiosos}

Los músicos que fueron procesados por la Inquisición pueblan los archivos históricos inquisitoriales de cualquier lugar que los conserve. Como el resto de la población, fueron susceptibles de ser denunciados anónimamente por proposiciones, deshonestidad, herejía o cualquier otro cargo. Como objeto de estudio

9. Iglesias Rodríguez, 2012a.

10. Dinges, 2013.

11. Fernández Castro, 2017. 
específico, la relación entre la Inquisición y la música o los músicos ha sido abordada por Miguel Ángel Picó ${ }^{12}$, llegando a la conclusión de que los músicos de Mallorca y Valencia que comparecieron ante este tribunal a fines del siglo XVI y comienzos del XVII no lo hicieron en tanto que músicos, sino por blasfemia o por sodomía ${ }^{13}$.

A la vista de los casos que ascendieron al Consejo de la Inquisición, la mayor parte de los músicos procesados por el Santo Oficio fueron denunciados por sus propios compañeros de trabajo, los demás músicos de su capilla o agrupación. Se puede comprender que las personas con las que pasaban buena parte de su tiempo tuviesen más ocasiones de conocer en profundidad su espiritualidad o sus convencimientos, y por ende sorprenderlos en falta. No obstante, teniendo en cuenta que la ejecución musical era un trabajo en equipo y que el enjuiciamiento de un miembro podía perjudicar la actividad cotidiana del conjunto, la inclinación de los músicos a denunciarse entre sí apunta a una fórmula entre otras para dirimir rencillas personales y rivalidades profesionales. De hecho, a veces el denunciante durante el proceso reconoció que no reinaba la armonía entre él y el denunciado, y que había sido él el primer en sonsacarlo e incluso servirle la situación en bandeja. En ocasiones, reunió a sus testigos entre el personal de la capilla: representantes de la sección de cantores, organistas y ministriles. Más aún, un denunciado podía convertirse en denunciante de otro miembro de su propia capilla musical ${ }^{14}$.

\subsection{Delitos contra la fe}

Los ejemplos del siglo XVII muestran una enorme inconsistencia en las denuncias, que fácilmente eran desestimadas por los tribunales. Eran tiempos de ortodoxia contrarreformista, de triunfo de las misiones interiores, lo cual hace sospechar que las proposiciones populares, las palabras inconvenientes que pudiesen escaparse de una boca poco prudente, no pasaban de emitir juicios personales sobre los comportamientos de las autoridades religiosas, sin que el pueblo fuese presa de grandes debates doctrinales. Los denunciantes trataron de explotar al máximo las connotaciones de expresiones preferentemente inocentes y casuales, con poco éxito en general. Por ejemplo, el músico y presbítero José de la Peña fue denunciado en la Puebla del obispo Palafox por valorar despectivamente el edicto de la Inquisición publicado, con las vagas palabras Ande vuestra merced, que hablan con pasión ${ }^{15}$. Por su parte, el presbítero y músico Juan García fue acusado de

12. Aunque su principal preocupación residía en la letra, la Inquisición ejerció un control sobre ciertos intervalos, saltos melódicos, disonancias, cromatismos, timbres e interpolaciones de material profano que se consideraron impropios de la música sacra, particularmente en los villancicos. Picó Pascual, 1999b.

13. Picó Pascual, 1999b; 1999a.

14. De hecho, José de la Peña en 1647 fue denunciado por Juan González pero él había declarado contra su compañero Juan García cuando éste fue acusado por un tercero. AHN, INQUISICIÓN, 1736, Exp.3.

15. AHN, INQUISICIÓN, 1736, Exp.26. 
haber atribuido cierto libelo anónimo a los jesuitas, a los que calificó de herejes, cismáticos, embusteros y odiados por todos ${ }^{16}$.

Un contexto distinto es la segunda mitad del siglo XVIII, en que las ideas de la Ilustración fueron calando en determinados sectores de la población hispánica hasta predisponerlos a posturas deístas, anticlericales e incluso descristianizadas. A pesar de la censura, los libros franceses penetraron en la península a través de sus puertos (Cádiz) y fronteras (Pirineos) con la mediación de comerciantes extranjeros y sus testaferros españoles ${ }^{17}$. La masonería fue condenada por el papa en 1738, lo cual desató una hornada de procesos de la Inquisición española hasta 1750, y en 1751 y en 1756, cuando se iniciaban sendas oleadas derivadas de las nuevas condenas de Benedicto $\mathrm{XIV}^{18}$, encontramos al primer músico, Francisco Rosell, de la capilla de palacio de Barcelona, acusado de masonería ${ }^{19}$. Por ello, no nos ha de extrañar que en 1783 un músico del Regimiento de Voluntarios de Cataluña ${ }^{20}$, natural de la villa tarraconense de Montblanc aunque se decía inglés, se hiciese eco de la irreverencia del otro lado de la frontera y perfectamente sobrio y ante variados testigos pretendiese transformar la jaculatoria Ave María Purísima en Putísima, que no saludase al Santísimo Sacramento y que se tocase con sombrero en la iglesia, que sostuviera que Dios estaba ausente de la eucaristía, que para la confesión no era necesario sacerdote ni templos, que sólo salvarían su alma los ingleses, que no diese crédito a la veracidad ni la autoría de los Evangelios, ni a la humanidad de Cristo, ni a la autoridad del pontífice, ni al entierro en suelo consagrado, y que todo lo manifestase en plena sacristía o iglesia, o que pidiese pruebas de lo contrario ${ }^{21}$. Estamos hablando de un ambiente militar, cosmopolita, relajado, en que debían de concitarse todas las actitudes.

Antes que eso, ya en 1755 encontramos el caso de un músico catedralicio con experiencia en Portugal e Italia que ante un sacristán se atrevía a sostener que el bautismo con agua era para los perros, que los niños merecían ser bautizados con vino, que la naturaleza era la creadora de todo, que Cristo no era más que un condenado y que siguiendo los dictados de la naturaleza era pecado la abstinencia sexual $^{22}$. Por citar otro caso, el organista de la catedral de Lugo en 1774, según sus compañeros músicos y sus familias, decía que las indulgencias y los sacramentos eran un latrocinio para que se mantuviesen cuatro desaprensivos, hablaba contra la venalidad de los sacramentos, la confesión auricular, los milagros, la monogamia y la abstinencia de comer carne. Al mismo tiempo, se mostraba proclive a los herejes, los judíos y los mahometanos. Él mismo admitió haber faltado a misa y

16. AHN, INQUISICIÓN, 1736, Exp.3.

17. Defourneaux, 1973, pp. 107-134.

18. Ferrer Benimelli, 1984, vol. I, pp. 1293-1300.

19. AHN, INQUISICIÓN, 3724, Exp.83.

20. Según las ordenanzas del ejército, la jurisdicción de la Inquisición se extendía sobre los militares en las causas de bestialismo y sodomía, las de irreverencia y escándalo, las de libros prohibidos, y las de herejía y apostasía. Díaz Rementería, 1997, pp. 212-213.

21. AHN, INQUISICIÓN, 3730, Exp.132.

22. AHN, INQUISICIÓN, 3728, Exp.24. 
llegado tarde con frecuencia ${ }^{23}$. Otro músico, en este caso de Barcelona, en 1778 sostenía junto con sus compadres que no existía el infierno ni el purgatorio, que se podía obrar contra el sexto mandamiento, que los santos no eran más que madera, que no había venido el Mesías, y tenía en su poder libros prohibidos ${ }^{24}$. En 1780 fue Luis Varayat, músico salmantino calificado como hombre libertino de muy malas costumbres porque en Madrid se jactaba de haber tenido varios cortejos, el cual fue denunciado por afirmar que el infierno no era más que un invento de los predicadores para asustar a los fieles ${ }^{25}$.

Ya al filo del siglo XIX, en 1791 encontramos las proposiciones más originales en boca de un organista milanés en el reino de Valencia, que a pesar de trabajar en iglesias y conventos aseguraba que los hijos engendrados por malos padres no recibían un alma creada por Dios sino uno de los espíritus expulsados del Paraíso que flotaban en el aire, que pasando de cuerpo en cuerpo podían llegar a redimir su pena. También se le atribuyó la creencia en las brujas y la opinión de que los españoles no guardaban la suficiente compostura en la iglesia ${ }^{26}$.

En el siglo XVIII, bajo la nueva dinastía, la Inquisición española continuó vigente, entendida por la monarquía como un instrumento político, y aunque desvitalizada demostró fuerza en la censura y prohibición de libros franceses y en el proceso de Pablo de Olavide ${ }^{27}$. Ante tan audaces proposiciones, los tribunales siempre se planteaban si los reos se encontraban bajo los efectos del alcohol, y los testigos siempre negaban dando argumentos en contra: uno de ellos era que si el reo hubiese estado ebrio no habría estado en condiciones de interpretar los papeles de música ${ }^{28}$. Todos estos músicos del siglo XVIII ya no fueron denunciados por otros músicos, sino por las personas que les rodeaban en su trabajo y se escandalizaron de su indiscreción a la hora de proclamar sus heterodoxias: vecinos, párrocos, sacristanes, monaguillos, etc.

De esta atmósfera desinhibida e irreverente, que ya no teme a la Inquisición ni a la censura social, da cuenta el caso de la misa de entierro que escenificaron teatralmente cinco vecinos de Lascuarre en Huesca en el martes de Carnaval, que debió de parecer un sacrilegio al párroco que los denunció. En este grupo estaban representados labradores, boticarios y también personal eclesiástico como el sacristán y el organista, los cuales fueron prendidos y recluidos en las cárceles secretas de la Inquisición con confiscación de sus bienes a pesar de que todo lo hicieron por bulla y fiesta, y no con fin depravado, habiéndose juntado la tarde mencionada en una placeta ${ }^{29}$.

23. AHN, INQUISICIÓN, 3726, Exp.137.

24. AHN, INQUISICIÓN, 3724, Exp.57.

25. AHN, INQUISICIÓN, 3730, Exp.218.

26. AHN, INQUISICIÓN, 3735, Exp.291.

27. Fuentes Monzó, 1975, vol. II, p. 203.

28. AHN, INQUISICIÓN, 3730, Exp.132.

29. AHN, INQUISICIÓN, 3732, Exp.438.

HID 47 (2020) 71-96 


\subsection{Delitos contra la moral}

Si bien la Inquisición nació como un tribunal para combatir la herejía, fue conquistando competencias de otros tribunales religiosos hasta extender su jurisdicción también hacia la inmoralidad ${ }^{30}$. Otra clase de delitos a los ojos de la Inquisición y otros tribunales religiosos eran los relativos a la moral sexual, que avanzada la Edad Moderna eran los más frecuentes que perseguía el Santo Oficio, ya erradicados los judaizantes y la generación reformadora de herejes. Antes de que abundaran los herejes de inspiración deísta, masónica o librepensadora, hubo una fase en la que la Inquisición no tuvo más víctimas potenciales que quienes tenían conductas sexuales alternativas: ${ }^{31}$ lo que se denominaba fornicación, sodomía y bestialidad $^{32}$. En 1750 un joven organista de Cariñena de 16 años se acusó ante la Inquisición de Zaragoza, impelido por su confesor y por saberse descubierto y acosado por testigos, de crimenes contra natura: de haber consumado el coito a lo largo de una temporada con distintos animales y con dos muchachos ${ }^{33}$. Estas acusaciones fueron muy reprimidas en 1570-1630, siendo luego más toleradas de hecho ${ }^{34}$.

Con todo, podemos encontrar antecedentes mucho más estrictos en el siglo XVI y en el siglo XVII. En 1570 había sido procesado el maestro de danza Antonio de Torres, de 20 años, que venía del Burgo de Osma y tenía una academia en Madrid, por sostener entre amigos en la taberna que tener relaciones con una mujer soltera no era pecado, venial a lo sumo, y que no era natural permanecer ocho días sin yacer con ninguna ${ }^{35}$. Sus amigos lo denunciaron cuando un sermón se pronunció en aclaración de la cuestión. No fue recluido, aunque se le prohibió abandonar Madrid sin licencia: fue condenado a oír misas rezadas con velas encendidas en la mano y a pagar cuatro ducados para los gastos del tribunal ${ }^{36}$.

Por su parte, veamos un ejemplo de músico denunciado por tener en entredicho su moralidad, cuyo único delito consistía en unas sospechas sobre su honestidad. En este caso no fue la Inquisición, sino la jurisdicción eclesiástica de Alcalá de Henares quien lo investigó, porque a pesar de que el individuo vivía y trabajaba en Cuenca, había sido estudiante de la universidad de Alcalá de Henares. Fue el caso de Juan Calvo, cantor presbítero de la iglesia de Santa María y San Julián de Cuenca (la catedral), que convivía con su hermana Ana Martín. Al cuestionarse

30. Consúltese González Polvillo, Antonio, 2011.

31. Para apreciar la variedad de conductas sexuales masculinas que eran reprobadas en la moral moderna por distanciarse de una masculinidad ideal, véase Alfieri, Fernanda; Lagioia, Vincenzo 2018. En dicho volumen, diversos autores repasan la actitud de los tribunales civiles y eclesiásticos ante lo que en el momento se consideraban desviaciones morales.

32. Peñafiel Ramón, 1996.

33. AHN, INQUISICIÓN, 3732, Exp.330.

34. Dedieu, 2013, pp. 452-453.

35. La condena de la fornicación con el pecado mortal fue una novedad de los años 70 del siglo XVI, en que los manuales de confesión pasaron a explicitarlo. Los procesos en torno a esta causa se agudizaron entre 1570 y 1635, aproximadamente. Dedieu, 2013, pp. 437-439.

36. AHN, INQUISICIÓN, 75, Exp.16. 
su parentesco y tomarlo por concubinato, no respondieron a las acusaciones ni se presentaron a las convocatorias, y apelaron la sentencia del juez provisor de Cuenca. Se averiguó que efectivamente eran hermanos aunque ella no era legítima, por lo que se le permitió mantenerla en su casa. El fallo los absolvió años después, en 16 de octubre de 1630. Obviamente ellos reclamaron las costas del pleito, que ascendían a 15.470 maravedíes $^{37}$.

En definitiva, a la vista de la muestra, los músicos que fueron denunciados a la Inquisición fueron más numerosos en el siglo XVIII en su segunda mitad que en el XVII. Entre ellos encontramos toda clase de músicos eclesiásticos (clérigos o seglares) y algunos militares. En todas las latitudes podemos localizar músicos que fueron acusados por las personas de su entorno, preferentemente profesional, mayormente de declaraciones heterodoxas realizadas en confianza aunque con poca discreción, dictadas por la exasperación y un anticlericalismo latente. La mayor parte de los denunciados se aventuraba a formarse su propia idea sobre lo trascendente y las obligaciones a las que se debía un cristiano; apenas hay alguna delación por aspectos ajenos a la religión, como la heterodoxia sexual.

Este tipo de delitos no fueron raros en los tribunales del Santo Oficio en el siglo XVIII, de hecho los estudios parciales que existen los registran con frecuencia ${ }^{38}$. Por lo tanto, se puede decir que los músicos que los cometieron no representan un grupo destacado, sino que comparten las tendencias del grueso de la población. En resumen, su comparecencia ante los tribunales religiosos fue independiente de su ocupación musical. Fueron denunciados por esta clase de delitos exactamente como cualquier otro tipo de individuos. Por lo tanto, la actividad musical de por sí no entrañaba riesgos específicos ni era examinada con sospecha.

Tabla 1. Selección de músicos denunciados ante tribunales religiosos (1600-1800)

\begin{tabular}{|c|l|l|c|l|l|l|}
\hline Denunciado & Profesión & \multicolumn{1}{|c|}{ Ciudad } & Fecha & Denunciante & Cargos & Fuente \\
\hline Juan Calvo & $\begin{array}{l}\text { Cantor } \\
\text { catedralicio }\end{array}$ & Cuenca & 1625 & $\begin{array}{l}\text { Jurisdicción ecle- } \\
\text { siástica de Alcalá de } \\
\text { Henares }\end{array}$ & Concubinato & $\begin{array}{l}\text { AHN, UNIVERSIDA- } \\
\text { DES, 307, Exp.2 }\end{array}$ \\
\hline José de la Peña & $\begin{array}{l}\text { Presbítero y } \\
\text { músico de la } \\
\text { catedral }\end{array}$ & $\begin{array}{l}\text { Puebla de los } \\
\text { Ángeles }\end{array}$ & 1647 & $\begin{array}{l}\text { Vecino Juan Gon- } \\
\text { zález }\end{array}$ & $\begin{array}{l}\text { Crítica a la } \\
\text { Inquisición }\end{array}$ & $\begin{array}{l}\text { AHN, INQUISICIÓN, } \\
\text { 1736, Exp.26 }\end{array}$ \\
\hline Juan García & $\begin{array}{l}\text { Presbítero y } \\
\text { músico de la } \\
\text { catedral }\end{array}$ & $\begin{array}{l}\text { Puebla de los } \\
\text { Ángeles }\end{array}$ & 1647 & $\begin{array}{l}\text { Organista Francisco } \\
\text { López }\end{array}$ & $\begin{array}{l}\text { Crítica a la } \\
\text { Compañía } \\
\text { de Jesús }\end{array}$ & $\begin{array}{l}\text { AHN, INQUISICIÓN, } \\
\text { 1736, Exp.3 }\end{array}$ \\
\hline
\end{tabular}

37. AHN, UNIVERSIDADES, 307, Exp.2.

38. En la Inquisición toledana durante el siglo XVIII se juzgaron delitos contra la moral como bigamia, deshonestidad, solicitación, matrimonio de clérigos, intrusismo en la misa o la confesión, delitos contra la fe como herejía, calvinismo, anglicanismo, luteranismo, molinismo, alumbradismo, incluso judaización, hechicería, sacrilegio, blasfemia, declaraciones escandalosas, delitos contra el propio Santo Oficio, delitos relacionados con libros prohibidos, francmasonería y otros delitos menores. A lo largo de este catálogo se presentan casos muy similares a los registrados entre los músicos de otros lugares. Galende Díaz, 1988, pp. 132-445. 


\begin{tabular}{|c|c|c|c|c|c|c|}
\hline Denunciado & Profesión & Ciudad & Fecha & Denunciante & Cargos & Fuente \\
\hline Juan Pacheco & $\begin{array}{l}\text { Músico } \\
\text { eclesiástico }\end{array}$ & Cuenca & 1755 & $\begin{array}{l}\text { Organista y sacristán } \\
\text { Andrés Rico }\end{array}$ & Herejía & $\begin{array}{l}\text { AHN, INQUISICIÓN, } \\
\text { 3728, Exp.24 }\end{array}$ \\
\hline $\begin{array}{l}\text { Esteban } \\
\text { Abadía }\end{array}$ & Organista & Zaragoza & 1750 & $\begin{array}{l}\text { Él mismo, inducido } \\
\text { por su confesor }\end{array}$ & $\begin{array}{l}\text { Bestialismo } \\
\text { y sodomía }\end{array}$ & $\begin{array}{l}\text { AHN, INQUISICIÓN, } \\
\text { 3732, Exp.330 }\end{array}$ \\
\hline $\begin{array}{l}\text { Francisco } \\
\text { Rosell }\end{array}$ & $\begin{array}{l}\text { Músico de } \\
\text { la capilla de } \\
\text { Palau }\end{array}$ & Barcelona & $\begin{array}{l}1751 \\
1756\end{array}$ & & Masonería & $\begin{array}{l}\text { AHN, INQUISICIÓN, } \\
\text { 3724, Exp.83 }\end{array}$ \\
\hline José Sopena & $\begin{array}{l}\text { Organista y } \\
\text { maestro de } \\
\text { niños }\end{array}$ & Zaragoza & 1768 & $\begin{array}{l}\text { Párroco Patricio } \\
\text { Martino }\end{array}$ & Sacrilegio & $\begin{array}{l}\text { AHN, INQUISICIÓN, } \\
\text { 3732, Exp.438 }\end{array}$ \\
\hline $\begin{array}{l}\text { Manuel } \\
\text { Méndez }\end{array}$ & $\begin{array}{l}\text { Organista de } \\
\text { la catedral de } \\
\text { Lugo }\end{array}$ & $\begin{array}{l}\text { Santiago de } \\
\text { Compostela }\end{array}$ & 1774 & & Herejía & $\begin{array}{l}\text { AHN, INQUISICIÓN, } \\
\text { 3726, Exp.137 }\end{array}$ \\
\hline Pablo Puig & $\begin{array}{l}\text { Músico } \\
\text { eclesiástico }\end{array}$ & Barcelona & 1778 & $\begin{array}{l}\text { Vecino Francisco } \\
\text { Baiona }\end{array}$ & Herejía & $\begin{array}{l}\text { AHN, INQUISICIÓN, } \\
\text { 3724, Exp.57 }\end{array}$ \\
\hline Luis Varayat & $\begin{array}{l}\text { Músico del } \\
\text { Regimiento de } \\
\text { Dragones de } \\
\text { Pavía }\end{array}$ & Valladolid & 1780 & $\begin{array}{l}\text { Vecina Teresa } \\
\text { Fuentes }\end{array}$ & Herejía & $\begin{array}{l}\text { AHN, INQUISICIÓN, } \\
\text { 3730, Exp.218 }\end{array}$ \\
\hline Odón Guasch & $\begin{array}{l}\text { Músico del } \\
\text { Regimiento de } \\
\text { voluntarios de } \\
\text { Cataluña }\end{array}$ & Llerena & 1783 & $\begin{array}{l}\text { Organista Manuel } \\
\text { Doblado }\end{array}$ & Herejía & $\begin{array}{l}\text { AHN, INQUISICIÓN, } \\
\text { 3730, Exp.132 }\end{array}$ \\
\hline $\begin{array}{l}\text { Angelo Santo } \\
\text { Michelo }\end{array}$ & $\begin{array}{l}\text { Salterista } \\
\text { y organista } \\
\text { eclesiástico }\end{array}$ & Murcia & 1791 & $\begin{array}{l}\text { Párroco de Onte- } \\
\text { niente }\end{array}$ & Herejía & $\begin{array}{l}\text { AHN, INQUISICIÓN, } \\
\text { 3735, Exp.291 }\end{array}$ \\
\hline
\end{tabular}

\section{TRIBUNALES CIVILES}

\subsection{Conflictividad laboral}

Los conflictos laborales entre músicos y sus empleadores fueron una constante en los siglos modernos, aunque es extraño que salten a los tribunales del reino. Los cabildos de la catedrales solían dirimir sus problemas con sus músicos con bastante independencia, tendiendo a la benevolencia pero sin temblarles la mano para, llegado el caso, despedirlos ${ }^{39}$. De hecho, en las fuentes internas de las catedrales abundan los conflictos con los músicos por absentismo o por indisciplina, que solían resolverse por votación en el cabildo. En estas fuentes, rara vez podemos oír la voz del músico, el cual parece asumir las consecuencias de su extralimitación. Son excepcionales los músicos que, en vez de resignarse a pedir perdón y la readmisión o buscar un nuevo patrón, lleven el asunto a los tribunales reales.

39. Véase Bejarano Pellicer, 2013, pp. 96-107. 
Con todo, en las fuentes judiciales descubrimos casos aislados: en 1558 el ministril salmantino Pedro de Nieva se querelló contra la catedral de Zamora por su contrato y por la fianza que le fue prestada ${ }^{40}$. Poco después, también el músico Ginés Bezón reclamó ante la real Chancillería los 13.166 maravedíes que el regidor de Toro don Antonio de Fonseca le debía de su salario por cantar y tañer para él y su familia durante un tiempo aun estando enfermo; aunque éste se resistiera e incluso apelara, el tribunal falló a favor del músico ${ }^{41}$. Ya en 1613, el ministril Francisco Sánchez denunció ante el corregidor al concejo de la ciudad de Soria porque a pesar de sus súplicas se resistía a pagarle su salario (de 333 reales y siete carretas de leña anuales) que le debía de cinco años y su salario del último año que ya montaba 1.000 reales y 20 carretas de leña. El concejo negaba haber firmado contrato con el ministril. Puesto que no consiguió lo que pedía, el músico recurrió a la Real Chancillería de Valladolid y esta vez sí obtuvo el pago de su salario de seis años en $1619^{42}$. En 1790 Antonio Martínez, el organista y sacristán de la parroquia de Cigales (Valladolid), denunció al alcalde por condiciones abusivas en su trabajo: le obligó a llevar a cabo el toque de queda y silencio en un largo período hasta el final de la vendimia ${ }^{43}$.

A fines del siglo XVIII en el mundo rural, en las fuentes judiciales podemos observar el fenómeno contrario: son las propias instituciones las que encausan a sus músicos. En 1771 es el concejo municipal guipuzcoano de Asteasun quien acude a los tribunales para deshacerse de un músico incómodo: denunció al organista y maestro local, Pedro Juan de Berridi, por haber usurpado el puesto al verdadero titular, apoderándose de las llaves del órgano ${ }^{44}$. También por otras cosas un organista pudo convertirse en reo por los recelos de sus empleadores: en 1796, en Cervera de Río Pisuerga (Palencia), el organista y sacristán de la iglesia parroquial fue culpado de un acto vandálico contra el patrimonio de la iglesia porque él era el custodio de las llaves ${ }^{45}$. Simultáneamente, en otro pueblo de Palencia llamado Santillana de Campos, el organista y sacristán también fue acusado de haber instigado a unos contrabandistas a saquear la tienda de un vecino y arrebatarle unos tejidos ${ }^{46}$. En 1798, el organista y sacristán de Tordehumos (Valladolid) fue condenado a prisión por haber tocado las campanas para cierta novena, a pesar de que era una de las competencias de su puesto, sin pedir la autorización preceptiva al concejo $\mathrm{o}^{47}$. Para comprender el sentido de este litigio, impensable un tiempo antes, hay que tener en cuenta la sensibilidad que la sociedad de la Ilustración desarrolló hacia los elementos propios de la religiosidad popular. La mentalidad ilustrada expresó su repugnancia hacia la abundancia de tañidos y campanarios en las poblaciones, no sólo porque temía los desprendimientos sino principalmente porque

40. ARCHV, pleitos civiles, Fernando Alonso (F), caja 3395, 4.

41. ARCHV, pleitos civiles, Fernando Alonso (F), caja 3395, 4.

42. ARCHV, registro de ejecutorias, caja 2286, 6 .

43. ARCHV, salas de lo criminal, caja 1305, 2.

44. ARCHV, pleitos civiles, PÉREZ ALONSO (OLV), caja 419, 2.

45. ARCHV, salas de lo criminal, caja 307, 9.

46. ARCHV, pleitos civiles, PÉREZ ALONSO (OLV), caja 751, 3.

47. ARCHV, salas de lo criminal, caja 1, 2 . 
siendo una herramienta religiosa gobernaba la vida civil ${ }^{48}$. Es obvio que en 1798 el concejo luchaba por subordinar la influencia social de la Iglesia a sus directrices y el tañido de las campanas tenía que pasar por su control.

Todos estos son ejemplos de diferencias que se derivaban del trabajo cotidiano de los músicos de toda índole, y que rara vez desembocaron en un pleito. Se debe entender que encubren un fenómeno mucho más extendido que, en el ámbito catedralicio, se puede testar en la documentación interna y en otros ámbitos pasa absolutamente desapercibido. Por lo que parece que cuanto más avanzada estuvo la Edad Moderna más se reflejó en los tribunales.

\subsection{Rivalidad entre músicos}

Otro de los campos en los que podían colisionar los intereses de los músicos era en la publicación de obras. En una sociedad proteccionista como la castellana, los derechos de impresión de obras musicales se concedían como privilegio y la violación de esta exclusividad era motivo de denuncia. Ante el Consejo de Castilla encontramos denuncias que sí están directamente relacionada con el oficio musical, en las que se revela la conflictividad profesional entre quienes lo ejercían. Se conserva un largo pleito en el que aquel que posee la licencia para imprimir música en exclusiva, el organista José de Torres, denuncia en 1711 a un colega, el clarinero de la Real Capilla Francisco Díaz de Guitian, por haber impreso un método de música original. De hecho, el privilegio se le había concedido en 1700 por diez años y se le renovó tras su solicitud en 1710. Francisco Díaz se defendió diciendo que su experiencia como docente doméstico le había hecho concebir un método revolucionario de aprendizaje musical que no podía quedar en la oscuridad y que tampoco era susceptible de ser impreso por otras manos por ser demasiado innovador. Para rebatir sus argumentos, José de Torres menospreció la inteligibilidad y la efectividad de su método. Entonces Francisco Díaz presentó algunas valoraciones positivas de maestros de música para avalar el interés de su trabajo, y el propio José de Torres le acusó de mendigar aprobaciones. El clarinero incluso presentó una misma pieza conocida de Antonio Literes transcrita mediante la notación tradicional y su propio método para que el Consejo se hiciera asesorar por expertos. Puesto que el 7 de marzo de 1711 la sala de gobierno del Consejo de Castilla falló a favor de José de Torres, su oponente decidió recurrir al Fiscal de Castilla ${ }^{49}$.

A su vez, en tribunales de asuntos criminales, también queda registrada la violencia interpersonal ejercida por un músico contra otro, presumiblemente por razones de competencia profesional. En 1780, un violinista del ámbito teatral podía llegar a atacar y herir a un compositor en un panorama efervescente de espectáculos escénicos cortesanos, como sucedió entre Cristóbal Andreosi y Pablo Estévez en Madrid $^{50}$.

48. Bejarano Pellicer, 2015, pp. 66-67.

49. AHN, CONSEJOS, 26565, exp.12.

50. AHN, CONSEJOS, 32026, exp. 2. 


\subsection{Músicos agredidos}

No obstante, por más enfrentamientos profesionales que llevaran a los músicos a las manos, abundan mucho más las ocasiones en que los músicos fueron víctimas de la violencia, y no agresores. Como músicos activos, a veces sufrieron los prejuicios y la agresividad de la sociedad. Cuando la música se utilizó de noche para fines de seducción o de vilipendio (esto es, como transgresión del orden social), sus tañedores se expusieron a las iras de mozos y estudiantes, que frecuentemente ejercieron la violencia anónima e impune contra ellos. Conservamos testimonios históricos y literarios del siglo XVII entre los que se cuentan Cervantes, Mateo Alemán, Castillo Solórzano y Luján de Saavedra ${ }^{51}$. En las fuentes judiciales también asoman indicios de esa conflictividad nocturna a partir del toque de queda. Por ejemplo, en 1629 dos hombres armados con espadas atacaron al ministril chirimía y bajonista Pedro del Castillo a las 9 de la noche en Talavera, cuando regresaba a su casa solo, y le hirieron en la cabeza y el brazo izquierdo: su padre, que también era ministril, reclamó 200 ducados de indemnización mientras él se reponía de sus heridas, puesto que estaba dejando de ganar su salario y gastando mucho en médico, cirujano, boticario y comida regalada o reconstituyente. El agresor dio otra versión en la que él invitaba a cenar al ministril y le daba un golpe accidental en la cabeza que desencadenaba la cólera y la agresividad del lesionado, y señalaba que sus heridas eran mucho más leves y baratas de atender de lo que pretendía. No obstante, fue condenado a un destierro de la villa de seis meses y a pagar 500 reales a la otra parte y 2.000 maravedís para los gastos del proceso ${ }^{52}$.

En 1636 en Alcalá de Henares tuvo lugar otro caso en el que se confunden la víctima y el agresor, y que viene a propósito para poner de manifiesto que los músicos no siempre fueron agredidos por capricho, por desconocidos, en razón de su oficio, sino por conflictividad laboral. Este pleito tuvo lugar ante la justicia de la Universidad por ser el denunciado graduado en dicho centro. El músico agredido, que era el joven organista de la iglesia de Santa María la Mayor de Alcalá de Henares, llamado Agustín Guillén Calderón, hijo del platero Ambrosio Carrillo y ciego para más señas ${ }^{53}$, se querelló contra el beneficiado de la iglesia, Francisco Lozano de la Peña, de 34 años. El músico pretendió que, al llegar una tarde a la iglesia, sin mediar provocación fue recibido a la puerta de la sacristía por el acusado a insultos (pícaro, soplón, borracho) y cinco o seis bofetadas, aunque sus dos testigos (su joven lazarillo y un presbítero) añadieron un puntapié previo. De hecho, esta denuncia supuso al reo la reclusión en su casa y el embargo de sus bienes. Cuando fue interrogado dio una versión diferente de los hechos, mucho más completa y

51. Bejarano Pellicer, 2016.

52. ARCHV, registro de ejecutorias, caja 2517,62 .

53. Los ciegos en buena medida se dedicaron a oficios musicales en el Antiguo Régimen, particularmente a tocar el órgano, por ser un instrumento estático que no les exigía la movilidad de los demás. Encontramos organistas ciegos en todas sedes a lo largo de la Edad Moderna. La mayoría profesaban como clérigos e incluso desarrollaron teoría musical. Montoro Martínez, 1992, vol. II, pp. 175-270. Bejarano Pellicer, 2013, pp. 44-45. 
coherente. El músico se había ganado su desconfianza y animadversión tiempo atrás debido a su arrogancia, a haber desplazado del puesto de organista a un antecesor mucho más respetuoso con los clérigos, a haber declarado que tenía al consejo bajo su control, a haber obtenido un decreto para obligar a la iglesia a subirle el salario a pesar de que ya lo había declinado. También había demostrado su mal carácter cuando, frustradas sus gestiones por intervención del propio beneficiado Lozano, cayó en rabietas escandalosas:

se fue con mucha cólera diciendo les avía de llevar al consejo por ynobidientes y porque no servían bien la iglesia demás desto se gastó en muchas partes en especial en la madre de Dios diciendo que todos los clérigos de santa María estaban amancebados delante de algunos religiosos y de otras personas, “(...)” viendo avía gastado su dinero y no avía salido con lo que quería dijo el dicho Agustín Calderón y su padre que este confesante tenía la culpa de todo aviendo dado la traça y que asta beber de su sangre no avian de parar.

Por lo tanto, desde entonces el joven organista permanecía al acecho, espiando a los clérigos a hurtadillas. Ya había indispuesto al beneficiado con el patrón de una fundación de misas en la iglesia mediante chismes, sin que hubiera habido represalias; incluso se había tomado la libertad de divulgar la vacante del puesto de sacristán y había presentado a su propio lazarillo como candidato. Según el beneficiado, la agresión tuvo lugar a la puerta del cabildo pleno que los clérigos de la iglesia estaban celebrando para designar a un nuevo sacristán. El joven se presentó con su lazarillo y se hizo anunciar con tanta prepotencia, entró un monaguillo y dijo ay están el ciego y el que diçe a de ser sacristán diciendo lo a de ser a pesar de todos los clérigos y que daría más fianças que toda Santa María, que el beneficiado fue el encargado de salir a expulsarlo. Según él, tan sólo lo acusó de acechar, pues estaba escuchando a hurtadillas, y le dio dos empellones para alejarlo de la puerta.

El pleito consta de muchos más testimonios a favor del uno y del otro, y de resultas acarreó al beneficiado muchos días de prisión domiciliaria y finalmente diez días de reclusión en la iglesia. Además le condenaron a pagar las costas del proceso, aunque recurrió el pago de las costas, que montaban 7.474 maravedíes las que tocaban a Agustín Calderón ${ }^{54}$. Quizá lo más ilustrativo del caso es que el organista de una iglesia, por más joven y miserable que pudiera parecer, se convertía en una figura inevitable que interaccionaba con los demás cargos, construía sus propias redes clientelares, aspiraba a mejorar sus condiciones y podía conspirar activamente en la vida parroquial. Podemos dar por cierto que el joven Agustín Calderón fue agredido, si aceptamos sus palabras, no por algo relacionado con su oficio ni por reivindicar un mejor salario -que por otro lado necesitaba ya que su familia se moría de hambre-, sino por los métodos que adoptó, al traicionar a sus propios empleadores.

54. AHN, UNIVERSIDADES, 308, Exp.2. 
Otro pleito de 1679 en Alcalá de Henares también nos muestra a un músico agredido gravemente por alguien de su entorno, un conocido ofendido no tanto por su proceder como por sus maneras arrogantes. En este caso, la víctima no era un muchacho ensoberbecido, sino un hombre de 33 años con una posición consolidada en la organistía del Colegio Mayor de San Ildefonso de Alcalá de Henares ${ }^{55}$. Como el joven Agustín Calderón, él mismo se buscó la agresión mediante provocaciones, pero tuvo el buen juicio de negarse a denunciarlo, de forma que hubo de hacerlo el procurador síndico de la audiencia escolástica de la propia universidad. El ataque aconteció ante muchos testigos, cuando el organista, Antonio Delmás Ibáñez, fue a entregar al notario un mandamiento de ejecución ganado ante la universidad por las rentas de un arrendamiento. Juan de Magaña, la víctima, que fue despojada en el acto de su capa, no supo gestionar emocionalmente la humillación: cuando el organista anunció que también ejecutarían los bienes de su suegra Ángela de Rabaneda, Juan de Magaña perdió los estribos: prorrumpió en juramentos y amenazas. Ante las repetidas invitaciones de Delmás para que cumpliese su bravata, lo atacó y por encima de quienes los separaban le infligió una herida -grave al parecer del cirujano- en la cabeza con la espada. Los testigos afirmaron que ambas partes solían bromear e incluso retarse, luego la reacción de Magaña había sido inesperada. Aunque éste huyó de la justicia, sus bienes fueron embargados y se le destinaron a su víctima 106 reales de vellón para que se alimente y cure ${ }^{56}$. Por lo tanto, éste se puede clasificar como un conflicto derivado no tanto de una disputa económica como personal.

Ya en el siglo siguiente, Francisco Prieto fue víctima de una agresión cuando tocaba con otros músicos en la puerta de una iglesia de su pueblo, Villanueva de Duero, en 1755, por lo cual la sala de lo criminal de la Real Chancillería de Valladolid abrió una investigación ${ }^{57}$. Si sus compañeros de profesión no fueron víctimas de la misma agresión, eso significa que la culpa que se le atribuía no residía en su calidad de músico, sino que subyacía un conflicto personal. A otro nivel ofensivo, al tamborilero Felipe Vélez Marieta le fue negada la comunión en Valmaseda, en Vizcaya, en 1791, hecho que desencadenó un pleito en el que el demandante ni siquiera era el interesado ${ }^{58}$.

55. El colegio mayor de San Ildefonso de la Universidad de Alcalá de Henares contaba una iglesia, centro institucional y físico de la Universidad, con sus propios ministriles, capellanes y cantores, al igual que la Magistral de Alcalá de Henares, y ambos cuerpos interaccionaban en las fiestas públicas. Procesionaban y tocaban trompetas y atabales desde lo más alto del edificio en 1556 al levantar pendones por el nuevo rey Felipe II; también participaron en las exequias de Carlos V en 1558. González Ramos, 2006, pp. 148-151. Los capellanes eran 12, se dedicaban al culto, a celebrar misas y vísperas solemnes. Entre los oficiales del colegio de San Ildefonso se encontraban el organista, con 8.000 maravedíes de salario al año, y los ministriles que sumaban 8.164 en 1565-1566. González Navarro, 1999, p. 71. En la iglesia existía desde sus orígenes una tribuna de madera para los órganos, que fue pintada y dorada por Francisco de las Pozas y Pedro de San Martín, y un órgano construido por el toledano Nicolás Pérez en 1510, que debía ejecutar e instalar en poco más de seis meses. González Ramos, 2006, pp. 49-50. García Oro, 1992, pp. 83-84. Ya en el curso 1514-1515 aparece en la documentación económica un organista llamado Herrera. González Navarro, 1998, p. 81.

56. AHN, UNIVERSIDADES, 313, Exp.28.

57. ARCHV, salas de lo criminal, caja 612,3 .

58. ARCHV, pleitos civiles, Pérez Alonso (OLV), caja 1265, 14. 


\subsection{Músicos criminales}

Los delitos más graves de que se acusa a los músicos ante los tribunales no son de sangre en su mayoría, a pesar de que el patrón criminal de tipo preindustrial contabiliza más crímenes de violencia interpersonal que contra la propiedad ${ }^{59}$. En 1630 fue acusado por lo criminal el músico Juan del Portal, que a pesar de ser hijo de cerrajero trabajaba como ministril de la catedral de Burgos y se reputaba como maestro particular de guitarra. Doña Inés de Mayorga de Gamarra lo denunció por haber seducido a su hija de doce años, doña Juana de Amasa, a la que impartía clases de guitarra a domicilio (al precio de 12 reales al mes), obteniendo promesa de matrimonio de ella con testigos por medio de la promesa de una sortija de oro y de la mediación de una celestina, Ana Hurtado, antigua criada de la casa, comprada con 20 reales. Aunque obtuvo su palabra de matrimonio supuestamente para ganar una apuesta, puso un pleito matrimonial a la doncella e intentó raptarla del beaterio de las recogidas donde estaba acogida. El músico negaba casi todo, insistía en el consentimiento de la muchacha. Aunque durante el pleito estuvo preso en la cárcel real, fue liberado tras presentar fiadores, con orden de alejamiento so pena de destierro y multa. Finalmente fue condenado a seis años de destierro de Castilla y destierro perpetuo de Burgos, y una multa de 50.000 maravedíes para los gastos del proceso $^{60}$.

Paralelo a este caso pero bien entrado el siglo XVIII ofrezcamos el del organista de una parroquia de Logroño, Esteban Ladrón de Guevara, quien en 1777 fue acusado de adulterio con una vecina, siendo clérigo de menores ${ }^{61}$. Como se puede ver, los delitos contra la moral sexual afectaban tanto a la justicia civil como a la religiosa, desde un extremo a otro del período.

Pero no sólo los asuntos del corazón tentaban a los músicos, sino también los del peculio. En 1793 también encontramos a un presbítero organista de una parroquia de Aranda de Duero envuelto en una trama de juego a la banca junto con otros clérigos y vecinos ${ }^{62}$. Excepcionalmente aflora en la documentación algún caso de un músico procesado por un verdadero crimen, como fue el caso de Francisco Lázaro Muñoz, sacristán y cantor del Colegio Mayor de San Ildefonso de la Universidad de Alcalá de Henares, de unos 30 años, que fue detenido y condenado junto con una banda de ladrones a la que pertenecía en 1699. En una ciudad universitaria con tanta entidad como la complutense, la jurisdicción universitaria planteaba problemas limítrofes con la jurisdicción ordinaria desde los primeros tiempos ${ }^{63}$. Aunque fue la justicia civil la que lo apresó, la universitaria lo reclamó para su propia prisión y, habiendo descerrajado su cubil, embargó sus escasos bienes y los remató en almoneda pública poco después.

\footnotetext{
59. Llanes Parra, 2013.

60. ARCHV, registro de ejecutorias, caja 2561, 46.

61. ARCHV, Sala de lo criminal, caja 1471, 1.

62. ARCHV, Sala de lo criminal, caja 725, 1.

63. González Navarro, 1999, pp. 77-80.
} 
Entre sus enseres inventariados se puede destacar como identitarios su sotana negra vieja, ocho libros y una vihuela para desempeñar su trabajo musical. El reo afirmaba que simplemente la banda de ladrones le propuso saquear el oro y la plata de la casa de un hombre acomodado, reteniendo a sus habitantes en el sótano y ejerciendo la violencia contra ellos si no se sometían. No obstante, se ganaba su humilde existencia con muy variadas actividades, ya que fue prendido precisamente por cometer la torpeza de visitar a un conocido en la cárcel para reclamarle los 14 reales que le debía por enseñar a leer a sus hijos ${ }^{64}$. Es obvio que la alfabetización y la destreza musical (vocal e instrumental) no salvaban a un hombre de la pobreza a fines del siglo XVII.

Al final del período, en 1796, encontramos a un músico agresor. En Torquemada (Palencia), dos jóvenes atacaron e hirieron a Vicente de Lerma López, soldado veterano del Regimiento de Infantería de la Princesa, que estaba abrevando a sus caballos en el puente de la localidad. Puesto que eran vecinos, todos debían de conocerse y abrigar alguna rencilla. Uno de los jóvenes era mancebo de cirujano y el otro aprendiz de organista ${ }^{65}$. Sin llegar a las manos, el organista y sacristán de Mazariegos (Palencia), José París, ya en 1760 fue denunciado ante la Real Chancillería de Valladolid por injuriar a su vecino ${ }^{66}$.

\subsection{Músicos deudores}

Los músicos siempre fueron un grupo socioprofesional que por su estilo de vida, en gran medida migratorio, fueron proclives a hacer uso del crédito y acumular deudas. Por ello, en la documentación notarial y de sus instituciones empleadoras abundan las referencias a sus obligaciones. Es lógico que algunas de esas deudas desembocasen en los tribunales por impago, aunque examinando los fondos judiciales tan sólo podamos apreciar la punta del iceberg. Por ejemplo, en 1601 el organero extranjero Claudio Girón y su mujer Isabel García, vecinos de Madrid, fueron condenados a redimir un censo de 800 reales sobre una casa de los hortelanos Miguel de Cuadros y Catalina de Valdemoros, comprado cuatro años antes, en un momento de bonanza en que Madrid aún era corte, a instancias del panadero francés Antón Esterna, su fiador ${ }^{67}$. Esta deuda llevó al organero a la cárcel. $\mathrm{Al}$ año siguiente, todavía presos de la crisis económica, pedían más tiempo para saldar deudas por valor de 5.324 reales. Sus acreedores eran el citado panadero, un mesonero, un ropero y un maestro de guarnecer coches reales, con los que consiguieron un concierto para renegociar su deuda y pagarla a lo largo de seis años. El único que se opuso y apeló fue el mencionado Antonio Esterna, lo cual sugiere algún empeño personal ${ }^{68}$.

\footnotetext{
64. AHN, UNIVERSIDADES, 316, Exp.20.

65. ARCHV, Sala de lo criminal, caja 46, 3 .

66. ARCHV, Sala de lo criminal, caja 2058, 8 .

67. ARCHV, Registro de ejecutorias, caja 1930, 83.

68. ARCHV, registro de ejecutorias, caja 1929, 51.
} 
Si nos trasladamos a Barcelona, en 1605 el músico Joan Utgés fue demandado por no devolver ni pagar una mula alquilada a la que habían matado los bandidos durante su viaje ${ }^{69}$. En otro caso de 1609, Juan Sánchez, ministril del colegio de San Ildefonso de la universidad de Alcalá de Henares, se resistía a aceptar las sucesivas tasaciones de la obra que el albañil Francisco Aguado había hecho en su casa, interrumpida por su muerte, porque dichas tasaciones arrojaban un monto desfavorable para él, y así estuvo pleiteando con la viuda de éste, María de Aguilar, ante la justicia civil de Alcalá de Henares y más tarde recurrió a la Real Chancillería de Valladolid, que no hizo más que confirmar la sentencia del alcalde mayor local a favor de la viuda ${ }^{70}$. En 1624, la viuda Luisa de Espinosa se querellaba contra el ministril de Talavera Francisco Gutiérrez por haberle vendido a su difunto marido unas casas en la calle nueva de Palacio de Madrid sin haberle advertido de que sobre ellas pesaba el pago del derecho de la veintena a la parroquia de Santiago: 500 maravedíes de censo perpetuo. La Real Chancillería de Valladolid le dio la razón a ella ${ }^{71}$.

En 1630, el organista Francisco Téllez de la palentina villa de Amusco debía 76 reales al cobrador de las alcabalas del vino por haber vendido vino sin haberlo declarado. Recurrió porque se le embargaron varios muebles de su casa para liquidar esta deuda, cuando según él debería estar exento por su condición de clérigo de órdenes menores y por el privilegio que tenía asignado su oficio de organista de la villa ${ }^{72}$.

El impago de rentas y censos por propiedades inmobiliarias fue lo más frecuente en llegar a los tribunales, en la medida en que la mayoría de la población vivía en inmuebles ajenos. En 1695 Salvador Pérez y Carreras, que era tornero y músico, tuvo que comparecer ante la Real Audiencia de Cataluña por no pagar el censal de una casa de la calle Flassaders de Barcelona ni querer dejarla ${ }^{73}$. En la misma línea, en 1732 el músico Esteban Salvat y el tejedor Josep Massó se vieron denunciados porque, como tutores y curadores del menor Cristóbal Salvat, debían reconocer poseer unas casas en Barcelona y pagar el correspondiente censo a un clérigo $^{74}$.

Pero veamos un ejemplo de deudas más jugoso. En 1647, esta vez en Alcalá de Henares, el médico Juan de Gonzalo se querelló ante la justicia universitaria contra el ministril Francisco Sevillano, que trabajaba en la capilla de música de la iglesia Magistral de la ciudad, porque había administrado con mano demasiado liberal las rentas que aquel le había encomendado durante su ausencia de varios años de la ciudad, mientras estuvo ejerciendo la medicina en Molina de Aragón. De hecho, el rector hizo que se ejecutase la deuda en sus bienes en poco tiempo, empezando por la capa de paño negro que traía puesta. Se adjunta un inventario

69. ACA, Real Audiencia, Pleitos civiles, 25164.

70. ARCHV, registro de ejecutorias, caja 2100, 17.

71. ARCHV, registro de ejecutorias, caja 2394, 14.

72. ARCHV, registro de ejecutorias, caja 2544, 39.

73. ACA, Real Audiencia, Pleitos civiles, 24223.

74. ACA, Real Audiencia, Pleitos civiles, 16619. 
de los bienes embargados, compuesto por abundantes muebles de nogal entre los que destacan los de despacho, muchas obras de arte sacro en su mayoría, textil de hogar, indumentaria masculina y femenina, menaje de cocina y calefacción y cuatro tinajas de vino a medio consumir.

¿Por qué las rentas del galeno estaban en manos de un músico? Éste era el cuñado de 40 años del médico, de hecho hijo de su suegro. Si bien Juan de Gonzalo estimó que la mala gestión de su cuñado había redundado en una pérdida de 7.242 reales de vellón, éste no aceptaba una deuda mayor de 240, porque de lo demás decía poseer documentos (cartas personales con órdenes de pago) que justificaban la donación de Juan de Gonzalo. De hecho, emprendió una enérgica defensa, con la animosidad que es propia entre parientes. Argumentó que en todos los años que llevaba administrando esas rentas las había salvado de muchas otras pérdidas, por lo cual ya que Juan de Gonzalo se había beneficiado de sus buenas gestiones también debería asumir sus fracasos. Presentó a cuatro testigos, entre los cuales se encontraba un mercader y un estudiante. Lo que es más importante, hizo que su esposa Ángela Manuel reclamase los 5.185 reales de vellón de ajuar y los 100 de arras de que se componía su dote, para que no se le embargaran a su marido, como primera acreedora del mismo. Puesto que se adjunta una copia de la carta de dote, se puede apreciar cada uno de los elementos de ajuar tasados en 1638, cuando el ya ministril de la iglesia Magistral desposó a su mujer. Abundan los textiles del hogar, la indumentaria femenina y masculina, las obras de arte sacro, algún mueble, menaje de cocina y vajilla, joyería y dinero en efectivo y en cartas de pago a favor. La pieza más valiosa era un hábito de sempiterna (paño), junto con la cama y los colchones.

Esta maniobra obligó al rector a poner en depósito esta cuantía, a lo que reaccionó Juan de Gonzalo asegurando que la pareja tenía otros bienes ocultos e incluso presentó una memoria de ellos, que incluía tierras, una vajilla de plata, vino, cartas de deuda a favor, joyas, una cama, una escultura del Niño Jesús, un arcabuz de 300 reales, lujosos vestidos de 1.000 reales y otras cosas, destacando lo que nadie había mencionado antes: el salario que cobraba el ministril de la Yglesia, collegio, y otras partes, lo cual nos muestra que los músicos eran pluriempleados que prestaban servicios a todas las instituciones y particulares de la ciudad. Francisco Sevillano y su mujer juraron que habían vendido estos bienes durante sus nueve años de matrimonio, entre otras necesidades para mantener al hijo de Juan de Gonzalo, el cual vivió en la casa de ellos durante cuatro años mientras estudiaba en la universidad, enviado desde Molina de Aragón por su padre a casa de sus tíos recién casados, sin que nadie les pagara nada en compensación por la estancia de su sobrino. También mencionaron que se habían visto obligados a vender bienes para sustentar a su pariente Diego Sevillano, el suegro de Juan, para comprar el vino que tenían y para rescatar que no fuese por soldado Juan Manuel, el hermano de Ángela. El médico Juan de Gonzalo convocó testigos para someterlos a un interrogatorio sobre esto. No obstante, la universidad falló que Juan de Gonzalo no había probado sus acusaciones, por lo que a Ángela le correspondía ser pagada de su dote y arras en primer lugar, 
por consiguiente se alzaban los embargos hechos sobre los bienes de Francisco Sevillano ${ }^{75}$.

Este rico pleito nos ofrece una ingente documentación sobre la cultura material y la posición económica de un músico con nómina en la principal iglesia de una ciudad universitaria, además de revelarnos cuáles eran sus conexiones familiares. Aunque Francisco Sevillano se casó con una mujer bien dotada y gozaba de salario y otros ingresos derivados de su trabajo, las fuentes nos confirman que no vivía con holgura, sino que para hacer frente a dificultades familiares debía vender bienes e incurrir en deudas.

Esta idea se refuerza a la vista de un nuevo pleito de 1650, en el que el racionero de la Magistral Diego Monje denunció a un ministril de la ciudad llamado Ignacio de Salinas, que en esas fechas ya formaba parte de la capilla de la catedral de Valladolid pero que al ser vecino de Alcalá debió de trabajar en la Magistral y ser su compañero de trabajo cuando sucedieron los hechos. La causa fueron varios préstamos por valor de 50 ducados que el ministril no había devuelto, aunque llevaban vencidos un año. A 13 de febrero de 1651 se llevó a cabo la ejecución en Valladolid en la capa de bayeta que llevaba Ignacio de Salinas (que según los fiadores valía los 50 ducados, décima y costa), y en septiembre en su casa, que estaba enfrente de la catedral. El despojado nombró como fiadores (para no ir a la cárcel como garantía) a Bartolomé de Salazar procurador de Valladolid y a Francisco González de Ávila ministril de la catedral de Valladolid. Aunque el procurador elevaría un recurso, la universidad de Alcalá de Henares (ante la cual se había querellado el racionero por ser maestro graduado en ella) falló en favor de la justicia de la ejecución pedida ${ }^{76}$. Por lo tanto, en breve plazo de tiempo fueron dos los ministriles de la Magistral de Alcalá de Henares ejecutados por deudas, lo cual no invita a estimar muy bien el salario que percibían.

Todavía a fines del período encontramos pleitos como el de Manuel Llorente, el organista y sacristán de la villa de Melgar de Yuso, en Palencia, que fue acusado por los demás beneficiados de la iglesia donde ejercía de haberse llevado más rentas de la cilla eclesiástica de la que le correspondía a cada uno ${ }^{77}$.

\subsection{Músicos acreedores}

No siempre los músicos eran demandados por impago. Al revés, en 1610 el ministril de Plasencia Bartolomé Navarro denunció que el regidor Pedro de Montemayor y sus hermanos le habían vendido una viña sin advertirle de que sobre ella pesaba una hipoteca de 12.000 maravedíes anuales de renta, por cuyo impago le fue embargada. Sus estafadores fueron condenados por la justicia ordinaria y acabaron elevando el caso a la Real Chancillería de Valladolid para no obtener más que la confirmación de la sentencia anterior ${ }^{78}$.

75. AHN, UNIVERSIDADES, 261, Exp.77.

76. AHN, UNIVERSIDADES, 262, Exp.70.

77. ARCHV, registro de ejecutorias, caja 3670,16 .

78. ARCHV, registro de ejecutorias, caja 2225, 33 . 
En otro caso comparable, el ministril de la Universidad de Alcalá de Henares Baltasar del Castillo, debió de sufrir una estafa cuando prestó 210 reales a un estudiante universitario llamado Antonio Lagasca en 1638 para que se lo devolviera en una semana, y al cabo de los tres meses tuvo que denunciarlo a la jurisdicción de la universidad, para descubrir que las sábanas que le había dejado como fianza no eran suyas sino de un supuesto Damián de Espinosa residente en Zaragoza a quien el ministril no conocía, el cual decía ser también el beneficiario del préstamo ${ }^{79}$.

En 1620 un cantor contralto de la catedral de Toledo, llamado Juan de Vera, denunció a su vecino Matías Rodríguez porque, habiendo cobrado y administrado su prebenda de cantor (rentas, gajes y frutos) durante dos años, al vencimiento del poder otorgado se resistía a que se sentaran a hacer cuentas. Éstas fueron realizadas por la justicia ordinaria y supusieron, como era de esperar, una ejecución de la deuda que Matías Rodríguez había contraído con Juan de Vera, cifrada en 2.426 reales. No obstante, aquel presentó al alcalde mayor otro cálculo, según el cual Juan de Vera le debía a él 1.493 reales. Finalmente se falló a favor de Matías Rodríguez, a quien se le devolvió lo embargado, y en contra de Juan de Vera; éste recurrió a la Real Chancillería de Valladolid, quien le dio la razón a él, condenando a Matías Rodríguez a pagarle 742 reales $^{80}$.

También un músico como el de la capilla musical de Santa María de Mar de Barcelona, Josep Ayguasanosa, en 1764 podía reclamar que su inquilino le pagase las pensiones vencidas por la tenencia de unas casas o que se marchase de ellas ${ }^{81}$. El organista de la villa de Ribas de Campo, Juan González, pleiteó con su arrendatario por las rentas en grano debido a que su organistía llevaba aparejado el beneficio de unas tierras ${ }^{82}$.

\subsection{Causas familiares}

Como miembros de sus propias familias, a veces los músicos comparecieron ante tribunales por asuntos que afectaban a sus parientes y al patrimonio familiar. Por ejemplo, en 1623 el organista Francisco Martínez por causa de su mujer se vio envuelto en un pleito con el monasterio benedictino de San Juan de Corias, en Asturias, que se había apropiado de tierra en la aldea de Carnero a raíz de un pleito con un tercero ${ }^{83}$.

De forma semejante, en 1645 Francisco de Vargas, el organista de la universidad de Alcalá de Henares (desde hacía casi un año estaba inscrito entre los oficiales de la institución), reclamaba a su vecino el frutero Juan González Bueno los 100 reales que le debía a su esposa María Truchado desde hacía unos seis meses

79. AHN, UNIVERSIDADES, 195, Exp.23.

80. ARCHV, registro de ejecutorias, caja 2335, 31.

81. ACA, Real Audiencia, Pleitos civiles, 20934.

82. ARCHV, registro de ejecutorias, caja 3637, 50.

83. ARCHV, registro de ejecutorias, caja 2360, 11. 
por reconocimiento escrito, más las costas del proceso. El origen de la deuda parece estar en las rentas de unas tierras propiedad de la mujer. La ejecución de sus bienes tuvo lugar inmediatamente y fue sancionada por el rector tras el recurso del afectado $^{84}$.

Más relacionado con la honra familiar se encontraba el caso del organista Cristóbal Suárez, que en 1648 en la Puebla de Montalbán denunció e hizo apresar in fraganti a Gabriel de Heredia, joven menor de veinte y cinco años, por trepar por las paredes traseras de su casa y colarse repetidamente en el aposento de su hija de madrugada y armado, y mancillar su virginidad bajo palabra de matrimonio. El joven fue condenado a, de no casarse con ella en un mes, dotarla con 1.000 ducados (aunque en apelación se le rebajaron a 3.000 maravedíes) y servir en el ejército de Cataluña durante cuatro campañas, so pena de cumplirlas en galeras, más 1.000 maravedíes para la cámara ${ }^{85}$.

En otro caso, en 1674 el mencionado Antonio Delmás Ibáñez, otro organista de la universidad de Alcalá de Henares de 28 años, se querelló ante la justicia universitaria contra el estudiante Diego Forcén, porque éste había abierto una puerta en el corral de su casa que lindaba con la vivienda del propio organista, en la calle mayor de la localidad. Todo apunta a que ambos actuaron en interés de sus respectivas madres, mencionadas en el pleito, en un conflicto de convivencia entre vecinos que fue resuelto a favor del organista en la universidad, aunque el estudiante apelaría al nuncio apostólico ${ }^{86}$. A la inversa, el músico Silvestre Farrer en 1702 se vio envuelto, junto a su madre, en un pleito movido por ellos contra un joven noble, por causa de unas obras que querían realizar en un patio que afectaba a la propiedad de éste ${ }^{87}$.

Pero los músicos no sólo se vieron obligados a cargar con las causas judiciales derivadas de su piedad filial. Los asuntos de un músico podían implicar a su viuda e hijo incluso después de su muerte, como sucedió en 1725 cuando los del organista catalán Carlos Milans se vieron demandados por el zapatero al que habían vendido un censal cinco años antes, por el cobro de las pensiones correspondientes ${ }^{88}$.

En definitiva, abundan los pleitos civiles en los que los músicos se revelan como arrendadores y arrendatarios, tutores y curadores de menores de edad, viajeros y demás roles típicamente urbanos. Los músicos no sólo tenían eventuales problemas con sus patrones, compañeros o rivales. Sus conflictos con el resto de la sociedad civil versaron sobre aspectos ajenos a su profesión, propios de la convivencia urbana y con intereses económicos implicados.

\footnotetext{
84. AHN, UNIVERSIDADES, 261, Exp.42.

85. ARCHV, registro de ejecutorias, caja 2764, 35.

86. AHN, UNIVERSIDADES, 204, Exp.37.

87. ACA, Real Audiencia, Pleitos civiles, 31408.

88. ACA, Real Audiencia, Pleitos civiles, 25000.
} 
Tabla 2. Selección de músicos denunciados ante tribunales civiles (1600-1800).

\begin{tabular}{|c|c|c|c|c|c|c|}
\hline Denunciado & Profesión & Ciudad & Data & Denunciante & Cargos & Fuente \\
\hline Claudio Girón & Organero & Madrid & 1601 & Antonio Esterna & $\begin{array}{l}\text { Impago de } \\
\text { deudas }\end{array}$ & $\begin{array}{l}\text { ARCV, registro de } \\
\text { ejecutorias, caja 1930,83 y } \\
1929,51 \text {. }\end{array}$ \\
\hline Joan Utgés & Músico & Barcelona & 1605 & $\begin{array}{l}\text { Notario Rafael } \\
\text { Pastor }\end{array}$ & $\begin{array}{l}\text { No devolución } \\
\text { de una mula } \\
\text { alquilada }\end{array}$ & $\begin{array}{l}\text { ACA, REAL AUDIEN- } \\
\text { CIA, Pleitos civiles, } 25164\end{array}$ \\
\hline Juan Sánchez & $\begin{array}{l}\text { Ministril de la } \\
\text { universidad }\end{array}$ & $\begin{array}{l}\text { Alcalá de } \\
\text { Henares }\end{array}$ & 1609 & María de Aguilar & $\mid \begin{array}{l}\text { Impago de una } \\
\text { obra inacabada } \\
\text { en sus casas }\end{array}$ & $\begin{array}{l}\text { ARCV, registro de } \\
\text { ejecutorias, caja 2100,17 }\end{array}$ \\
\hline Juan del Portal & $\begin{array}{l}\text { Maestro de } \\
\text { guitarra }\end{array}$ & Burgos & 1630 & $\begin{array}{l}\text { Doña Inés de } \\
\text { Mayorga }\end{array}$ & $\begin{array}{l}\text { Seducción de } \\
\text { doncella }\end{array}$ & $\begin{array}{l}\text { ARCV, registro de } \\
\text { ejecutorias, caja 2561, } 46 \text {. }\end{array}$ \\
\hline $\begin{array}{l}\text { Francisco } \\
\text { Sevillano }\end{array}$ & $\begin{array}{l}\text { Ministril de la } \\
\text { iglesia Ma- } \\
\text { gistral }\end{array}$ & $\begin{array}{l}\text { Alcalá de } \\
\text { Henares }\end{array}$ & 1647 & $\begin{array}{l}\text { Médico Juan de } \\
\text { Gonzalo }\end{array}$ & $\begin{array}{l}\text { Mala admi- } \\
\text { nistración de } \\
\text { rentas }\end{array}$ & $\begin{array}{l}\text { AHN, UNIVERSIDADES, } \\
\text { 261, Exp. } 77\end{array}$ \\
\hline $\begin{array}{l}\text { Ignacio de } \\
\text { Salinas }\end{array}$ & $\begin{array}{l}\text { Ministril de } \\
\text { la catedral de } \\
\text { Valladolid }\end{array}$ & $\begin{array}{l}\text { Alcalá de } \\
\text { Henares }\end{array}$ & 1650 & $\begin{array}{l}\text { Racionero de la } \\
\text { Magistral Diego } \\
\text { Monje }\end{array}$ & $\begin{array}{l}\text { Impago de } \\
\text { varios présta- } \\
\text { mos, vencidos } \\
\text { un año antes }\end{array}$ & $\begin{array}{l}\text { AHN, UNIVERSIDADES, } \\
262 \text {, Exp. } 70\end{array}$ \\
\hline $\begin{array}{l}\text { Salvador Pérez } \\
\text { y Carreras }\end{array}$ & $\begin{array}{l}\text { Tornero y } \\
\text { músico }\end{array}$ & Barcelona & 1695 & Administradores & $\begin{array}{l}\text { Impago de un } \\
\text { censal de una } \\
\text { casa }\end{array}$ & $\begin{array}{l}\text { ACA, REAL AUDIEN- } \\
\text { CIA, Pleitos civiles, } 24223\end{array}$ \\
\hline $\begin{array}{l}\text { Francisco Lá- } \\
\text { zaro Muñoz }\end{array}$ & $\begin{array}{l}\text { Cantor de la } \\
\text { universidad }\end{array}$ & $\begin{array}{l}\text { Alcalá de } \\
\text { Henares }\end{array}$ & 1699 & & $\begin{array}{l}\text { Robo organi- } \\
\text { zado }\end{array}$ & $\begin{array}{l}\text { AHN, UNIVERSIDADES, } \\
316 \text {, Exp. } 20\end{array}$ \\
\hline $\begin{array}{l}\text { Francisco Díaz } \\
\text { de Guitian }\end{array}$ & $\begin{array}{l}\text { Clarín de la } \\
\text { Real Capilla }\end{array}$ & Madrid & 1711 & $\begin{array}{l}\text { Organista José de } \\
\text { Torres }\end{array}$ & $\begin{array}{l}\text { Violación de } \\
\text { un privilegio } \\
\text { de impresión } \\
\text { musical }\end{array}$ & $\begin{array}{l}\text { AHN, CONSEJOS, 26565, } \\
\text { Exp.12 }\end{array}$ \\
\hline Esteban Salvat & Músico & Barcelona & 1732 & $\begin{array}{l}\text { Clérigo Gregorio } \\
\text { de Oliver y Mateu }\end{array}$ & $\begin{array}{l}\text { Impago del } \\
\text { censal de unas } \\
\text { casas }\end{array}$ & $\begin{array}{l}\text { ACA, REAL AUDIEN- } \\
\text { CIA, Pleitos civiles, } 16619\end{array}$ \\
\hline José París & $\begin{array}{l}\text { Organista y } \\
\text { sacristán }\end{array}$ & Palencia & 1760 & Antonio Díez & Injurias & $\begin{array}{l}\text { ARCV, salas de lo crimi- } \\
\text { nal, caja } 2058,8\end{array}$ \\
\hline $\begin{array}{l}\text { Pedro Juan de } \\
\text { Berridi }\end{array}$ & $\begin{array}{l}\text { Organista y } \\
\text { maestro }\end{array}$ & Guipúzcoa & 1771 & $\begin{array}{l}\text { Concejo de } \\
\text { Asteasun }\end{array}$ & $\begin{array}{l}\text { Usurpación del } \\
\text { cargo }\end{array}$ & $\begin{array}{l}\text { ARCV, pleitos civiles, } \\
\text { PÉREZ ALONSO (OLV), } \\
\text { caja 419, } 2 .\end{array}$ \\
\hline $\begin{array}{l}\text { Esteban } \\
\text { Ladrón de } \\
\text { Guevara }\end{array}$ & $\begin{array}{l}\text { Organista } \\
\text { parroquial }\end{array}$ & Logroño & 1777 & & Adulterio & $\begin{array}{l}\text { ARCV, salas de lo } \\
\text { criminal, caja } 1471,1\end{array}$ \\
\hline $\begin{array}{l}\text { Cristóbal } \\
\text { Andreosi }\end{array}$ & $\begin{array}{l}\text { Violinista } \\
\text { teatral }\end{array}$ & Madrid & 1780 & $\begin{array}{l}\text { Compositor Pablo } \\
\text { Estévez }\end{array}$ & $\begin{array}{l}\text { Injurias y } \\
\text { heridas }\end{array}$ & $\begin{array}{l}\text { AHN, CONSEJOS, 32026, } \\
\text { Exp. } 2\end{array}$ \\
\hline $\begin{array}{l}\text { Francisco } \\
\text { Alonso }\end{array}$ & $\begin{array}{l}\text { Organista y } \\
\text { sacristán }\end{array}$ & Palencia & 1790 & $\begin{array}{l}\text { Manuel López } \\
\text { Marcos }\end{array}$ & $\begin{array}{l}\text { Instigación al } \\
\text { robo }\end{array}$ & $\begin{array}{l}\text { ARCV, pleitos civiles, } \\
\text { PÉREZ ALONSO (OLV), } \\
\text { caja 751, } 3 .\end{array}$ \\
\hline $\begin{array}{l}\text { Fortunato Bua- } \\
\text { nalde }\end{array}$ & $\begin{array}{l}\text { Organista } \\
\text { parroquial }\end{array}$ & $\begin{array}{l}\text { El Burgo de } \\
\text { Osma }\end{array}$ & 1793 & & $\begin{array}{l}\text { Juego a la } \\
\text { banca }\end{array}$ & $\begin{array}{l}\mathrm{ARCV} \text {, salas de lo } \\
\text { criminal, caja } 725,1\end{array}$ \\
\hline $\begin{array}{l}\text { Francisco } \\
\text { Civera de la } \\
\text { Fuente }\end{array}$ & $\begin{array}{l}\text { Aprendiz de } \\
\text { organista }\end{array}$ & Palencia & 1796 & $\begin{array}{l}\text { Soldado Vicente } \\
\text { de Lerma López }\end{array}$ & Heridas & $\begin{array}{l}\text { ARCV, salas de lo } \\
\text { criminal, caja } 46,3\end{array}$ \\
\hline
\end{tabular}




\begin{tabular}{|l|l|l|c|c|c|c|}
\hline Denunciado & Profesión & \multicolumn{1}{|c|}{ Ciudad } & Data & Denunciante & Cargos & \multicolumn{1}{|c|}{ Fuente } \\
\hline Isidro Vela & $\begin{array}{l}\text { Organista y } \\
\text { sacristán }\end{array}$ & Palencia & 1796 & $\begin{array}{l}\text { Capellán y patrono } \\
\text { de una capellanía }\end{array}$ & Acto vandálico & $\begin{array}{l}\text { ARCV, salas de lo } \\
\text { criminal, caja 307, 9. }\end{array}$ \\
\hline $\begin{array}{l}\text { Manuel } \\
\text { Llorente }\end{array}$ & $\begin{array}{l}\text { Organista y } \\
\text { sacristán }\end{array}$ & Palencia & 1796 & Los beneficiados & $\begin{array}{l}\text { Apropiación } \\
\text { indebida de } \\
\text { rentas }\end{array}$ & $\begin{array}{l}\text { ARCV, registro de } \\
\text { ejecutorias, caja 3670,16 }\end{array}$ \\
\hline $\begin{array}{l}\text { Miguel Fer- } \\
\text { nández }\end{array}$ & $\begin{array}{l}\text { Organista y } \\
\text { sacristán }\end{array}$ & Valladolid & 1798 & $\begin{array}{l}\text { Alcalde ordinario } \\
\text { Tomás Díaz de la } \\
\text { Peña }\end{array}$ & $\begin{array}{l}\text { Toque de } \\
\text { campanas sin } \\
\text { autorización }\end{array}$ & $\begin{array}{l}\text { ARCV, salas de lo } \\
\text { criminal, caja 1,2 }\end{array}$ \\
\hline
\end{tabular}

\section{Conclusiones}

Observando la recurrencia de los músicos en los tribunales, se derrumba la idea preconcebida de que se trataba de un grupo especialmente delictivo. Su actividad como denunciantes no es escasa, lo cual podría justificar su fama de conflictivos, pero tengamos en cuenta que corresponde al afán pleiteante del período. Se les puede considerar un colectivo suspicaz, pero no son más numerosos los casos documentados que los impliquen en un rol que vaya más allá del de agraviado. Aproximadamente la mitad de las comparecencias son en calidad de víctima y denunciante, y no de acusado. Cuando eran los reos, los músicos solían haber cometido faltas civiles, relacionadas con la insolvencia en un $28 \%$ de los $\operatorname{casos}^{89}$, y rara vez demuestran actitudes criminales, entre las cuales no se puede observar un patrón: les perdieron asuntos de faldas en un $9 \%$ (seducción de doncellas, adulterio, concubinato), robo organizado o instigación al robo (6\%), creencias heréticas $(19 \%)$, comentarios desafortunados $(6 \%)$ o pendencias con derramamiento de sangre $(9 \%)$, entre otras causas más minoritarias.

El criterio geográfico no es relevante, ya que la tipología de las causas no difiere sustancialmente de acuerdo con el tribunal que las trata. El que sí es significativo es el parámetro cronológico, pues los casos del siglo XVII son menos numerosos que los del XVIII (en que los fondos conservados son más amplios), los cuales se multiplican en los últimos años de la centuria debido a una coyuntura de crisis del Antiguo Régimen y transformación de los valores predominantes ${ }^{90}$. Esta brecha en la segunda mitad del siglo XVIII se percibe especialmente en las causas religiosas, en que algunos músicos con conexiones internacionales parecen ser portadores de una nueva actitud descristianizada, pero también se percibe en las causas civiles: registramos delitos progresivamente más graves, como si el orden público se fuera minando simultáneamente.

89. De hecho, un estudio sobre los pleitos gaditanos de primera instancia de 1596-1735 arroja un $60 \%$ de delitos y conflictos de naturaleza económica, lo más frecuente. Pascua Sánchez, 2012, p. 167.

90. La conflictividad social del reinado de Carlos IV se ha justificado mediante la crisis finisecular, el desequilibrio entre población y recursos, la persistencia del elemento señorial, la tensión en torno a montes abiertos y tierras comunales, la presión fiscal y las crisis de subsistencias. Barreiro Mallón, 1991. 
Entre los músicos encausados, abundan los de ámbito eclesiástico (72 \%) entre cantores, organistas, ministriles y maestros, algunos de ellos clérigos o sacristanes. La figura del organista parroquial parece concitar todos los vicios y recelos, representando el $40 \%$. Raramente encontramos músicos militares o teatrales a fines del siglo XVIII. En cualquier caso, los músicos asentados en instituciones musicales son más proclives a denunciar y ser denunciados que los extravagantes o freelan$c e$, probablemente porque llevaban una vida más sedentaria y podían concitar mayores rencillas y fricciones con sus vecinos y compañeros, que son frecuentemente sus oponentes. La mayoría de los denunciantes fueron vecinos respetables y bien situados como médicos, notarios, clérigos, capellanes, cuando no instituciones colegiadas como los concejos. Por su parte, los músicos que se sintieron agraviados tampoco dudaron a la hora de pleitear con regidores, concejos, monasterios y cabildos eclesiásticos. Los músicos agredidos en su inmensa mayoría no lo fueron en el ejercicio de su oficio ni por causa de él, sino por motivos ajenos.

En definitiva, no puede esgrimirse una especificidad para el mundo de los músicos. Tan sólo pueden constatarse tendencias en el perfil del músico pleiteante, siempre teniendo presente que por muy proclive que la sociedad moderna fuese a acudir a los tribunales, no toda la población pudo hacerlo ni todos los delitos se dirimieron por esta vía. También entre los músicos se constata que el sector social mejor situado laboralmente también fue el más activo en la esfera judicial, lo cual subraya patrones generales.

\section{Bibliografía CITADA}

Alfieri, Fernanda; Lagioia, Vincenzo (eds) (2018), Infami macchie. Sessualità maschili e indisciplina in età moderna, Roma.

Barreiro Mallón, Baudilio (1991), "La conflictividad social durante el reinado de Carlos IV”, en Molas Ribalta, Pere (ed), La España de Carlos IV, Madrid, pp. 75-90.

Bejarano Pellicer, Clara (2012), "Disonancias en la armonía: música y conflictividad en el Siglo de Oro", en López-Guadalupe, Miguel Luis; Iglesias Rodríguez, Juan José (eds.), Realidades conflictivas. Andalucía y América en la España del Barroco, Sevilla, pp. 457-470.

Bejarano Pellicer, Clara (2013), El mercado de la música en la Sevilla del Siglo de Oro, Sevilla.

Bejarano Pellicer, Clara (2015), Los sonidos de la ciudad: el paisaje sonoro de Sevilla, siglos XVI al XVIII, Sevilla.

Bejarano Pellicer, Clara (2016), "Música y juventud en la primera mitad del siglo XVII español a través de la novela picaresca", Estudios Humanísticos. Filología, 38, pp. 145-170.

Dedieu, Jean Pierre (2013), "La sexualidad ante la Inquisición”, en Fortea, José (ed.) Furor et rabies: violencia, conflicto y marginación en la Edad Moderna, Santander, pp. 433-458. 
Defourneaux, Marcelin (1973), Inquisición y censura de libros en la España del siglo XVIII, Madrid, pp. 107-134.

Díaz Rementería, Carlos (1997), “Caracterización general de los delitos públicos por falsedad y escándalo en relación con la actividad inquisitorial en el siglo XVIII”, en Levaggi, Abelardo (coord.), La Inquisición en Hispanoamérica, Buenos Aires, pp. 212-213.

Dinges, Martin (2013), "El uso de la justicia como forma de control social en la Edad Moderna", en Fortea, José (ed.), Furor et rabies: violencia, conflicto y marginación en la Edad Moderna, Santander, pp. 47-68.

Fernández Castro, Ana (2017), "Entre la ley y la justicia: una aproximación a la cultura jurisdiccional castellana del siglo XVI a través de la experiencia de la Casa de la Contratación de Sevilla y del Consejo de Indias", Historia. Instituciones. Documentos, 44, pp. 77-101.

Ferrer Benimelli, J. (1984), "Inquisición y masonería”, en Pérez Villanueva, Joaquín; Escandell Bonet, Esteban (dirs.), Historia de la Inquisición en España y América, Madrid, vol. I, pp. 1293-1300.

Fuentes Monzó, Eduardo de (1975), "La Inquisición española en el siglo XVIII", en Homenaje al Dr. D. Juan Reglà Campistol, Valencia, vol. II, pp. 191-208.

Galende Díaz, Juan Carlos (1988), La crisis del siglo XVIII y la Inquisición española. El caso de la Inquisición toledana (1700-1820), Madrid, pp. 132-445.

García Oro, José (1992), La Universidad de Alcalá de Henares en la etapa fundacional (1458-1578), Santiago de Compostela.

Getz, Christine Suzanne (2005), Music in the collective experience in sixteenth-century Milan, Aldershot.

González Navarro, Ramón (1998), Universidad y economía: el colegio mayor de San Ildefonso de Alcalá de Henares (1495-1565), Alcalá de Henares.

González Navarro, Ramón (1999), Felipe II y las reformas constitucionales de la Universidad de Alcalá de Henares, Madrid.

González Polvillo, Antonio (2011), Decálogo y gestualidad social en la España de la Contrarreforma, Sevilla.

González Ramos, Roberto (2006), La Universidad de Alcalá de Henares y las Artes. El patronazgo artístico de un centro del saber. Siglos XVI-XIX, Alcalá de Henares.

Iglesias Rodríguez, Juan José (2012a), "Pulsiones y conflictos. Rupturas y formas de lo cotidiano", en Peña, Manuel (ed.), La vida cotidiana en el mundo hispánico (siglos XVI-XVIII), Madrid, pp. 217-237.

Iglesias Rodríguez, Juan José (2012b), “Tensiones y rupturas: conflictividad, violencia y criminalidad en la Edad Moderna”, en Iglesias Rodríguez, Juan José (ed.), La violencia en la historia: análisis del pasado y perspectiva sobre el mundo actual, Huelva, pp.41-91.

Llanes Parra, Blanca (2013), "La documentación de la Sala de Alcaldes de Casa y Corte como fuente para el estudio de la criminalidad madrileña del siglo XVII: problemática, desafíos y posibilidades", Clío y crimen, 10, pp. 245-259. 
López-Guadalupe, Miguel Luis; Iglesias Rodríguez, Juan José (eds.) (2012), Realidades conflictivas. Andalucía y América en la España del Barroco, Sevilla.

Lozano Navarro, Julián José; Castellano, Juan Luis (eds.) (2010), Violencia y conflictividad en el universo barroco, Granada.

Montoro Martínez, Jesús (1992), Los ciegos en la Historia, Madrid.

Pascua Sánchez, María José de la (2012), "Conflictividad, criminalidad y violencia en la época moderna: aproximación histórica desde la perspectiva integradora de la vida cotidiana", en Peña, Manuel (ed.), La vida cotidiana en el mundo hispánico (siglos XVI-XVIII), Madrid, pp. 157-176.

Peñafiel Ramón, Antonio (1996), "Inquisición y moralidad pública en la España del siglo XVIII”, Revista de la Inquisición, 5, pp. 293-302.

Picó Pascual, Miguel Ángel (1999a), "Música, músicos e Inquisición en la Valencia postridentina e ilustrada”, Revista de la Inquisición, 8, pp. 193-213.

Picó Pascual, Miguel Ángel (1999b), “Música, poder e Inquisición en la España del Antiguo Régimen”, Saitabi, 49, pp. 375-393.

Rostirolla, Giancarlo (1994), "Note e manette: documenti su musici, costruttori e teatri dalla Miscelanea Artisti”, en Antolini, Bianca; Morelli, Arnaldo; Spagnuolo, Vera Vita (comps.), La musica a Roma attraverso le fonti d'archivio, Lucca, pp. 79-105. 